\title{
Ecofeminismo para otro mundo posible
}

\author{
Alicia H. Puleo \\ Madrid: Cátedra. Colección Feminismos, 2011.
}

\section{Georgina Aimé Tapia González}

Escuela de Filosofía / Universidad de Colima, México georgina_tapia@ucol.com.mx

\begin{abstract}
Ecofeminismo para otro mundo posible representa una aportación fundamental para los feminismos hispanoamericanos, donde la reflexión sobre el vínculo entre las mujeres y el medio ambiente tiene una historia bastante reciente. En el ámbito específico de la filosofía ecofeminista,
\end{abstract}

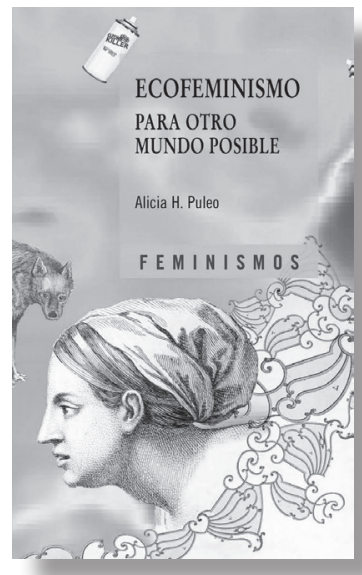
dad en los tiempos del cambio climático. Además, reivindica las contribuciones de las voces olvidadas del pensamiento ilustrado como fundamentos para un ecofeminismo crítico que rechaza los límites de la razón instrumental, pero discierne cuidadosamente entre los Alicia Puleo es una pionera en diversos aspectos del legado de el mundo latino. Su libro cons- la modernidad. tituye un puente que posibilita el encuentro y la comunicación entre las diversas voces del ecofeminismo y la ética ecológica. Es también una ventana que nos permite acceder a miradas múltiples y plurales sobre la reali-
La filósofa se distancia de planteamientos esencialistas que consideran que las mujeres son más cercanas a la naturaleza por sus características biológicas, lo que significa trasladar los estereotipos de género al ámbito de 
los movimientos ecologistas. Evidentemente, esto no contribuye al reconocimiento de que las mujeres, al igual que los varones, son personas. En tales posturas esencialistas, las madres-cuidadoras se convierten en salvadoras del planeta a quienes, no obstante, se les sigue negando su humanidad. Por el contrario, la fundamentación del ecofeminismo de A. Puleo es constructivista. De acuerdo con ella, las tareas del cuidado tienen que ser universalizadas. Valores como la compasión, la empatía y la solidaridad son imprescindibles para hacer frente a la crisis medioambiental. Se trata de una perspectiva ética que reclama la participación de todos los seres humanos y no sólo de las mujeres.

Es innegable que la ética del cuidado ha sido desarrollada a partir de las experiencias de aquéllas que, a lo largo de la historia, han sido las principales encargadas de las tareas de crianza y de preparación de los alimentos, así como de atender a las personas mayores y los problemas de salud de los integrantes de la familia. Sin embargo, para potenciar la igualdad de género ligada a la conciencia ecologista es imprescindible que las actividades relacionadas con el cuidado de otros seres vivos, humanos o no, sean asumidas también por los varones.

Alicia Puleo expone los ejes de su propuesta a través de los nueve capítulos que integran su libro. En el primero, subraya la importancia de una memoria ecofeminista que recoja diferentes perspectivas, desde los orígenes, en los ecofeminismos esencialistas, hasta las tendencias más recientes. Todos estos ecofeminismos se encuentran en su aspiración común de ofrecer alternativas ante un mundo alienado y consumista que ha llevado a la destrucción de la naturaleza, al aumento de enfermedades relacionadas con la degradación medioambiental y al sufrimiento de muchas personas, principalmente mujeres, afectadas por el cambio climáti$\mathrm{co}$, el uso indiscriminado de productos químicos, la falta de agua potable y la imposibilidad de acceder a alimentos no contaminados. Asimismo, muestra que las mujeres no solo son víctimas sino también sujetos activos en la preservación de la Naturaleza.

En los capítulos segundo y tercero, examina el legado de la Modernidad. Junto a la crítica de la instrumentalización de la Naturaleza, recupera argumentos poco conocidos de la Ilustración y muestra su potencial emanci- 
patorio. La autora recuerda que el pensamiento de la modernidad no puede reducirse al mecanicismo cartesiano. Rechazar en bloque los planteamientos de este periodo histórico significa ignorar las aportaciones de algunas pensadoras y pensadores que reclamaron el reconocimiento de las mujeres como ciudadanas, la abolición de la esclavitud y la extensión de la ética más allá de la especie humana. El desarrollo posterior del feminismo de orígenes ilustrados se esforzó en mostrar la falsedad de la identificación de las mujeres con la Naturaleza, mediante la cual se pretendía justificar su exclusión de la cultura. A. Puleo señala que las aportaciones de Simone de Beauvoir son fundamentales para comprender la compleja relación entre la opresión femenina y la asimilación de las mujeres a los ciclos de mundo natural, pero añade que la concepción beauvoriana de la Naturaleza necesita ser revisada tomando en cuenta nuevas problemáticas. Los límites del jardín ético propuesto por la filósofa francesa reclaman ser redefinidos a la luz de la crisis ecológica actual.

En los capítulos cuarto y quinto, aborda el tema de la sexualidad.Se pregunta sinuestra época es un nuevo helenismo donde la trasgresión no es sino una nueva cara detrás de la cual se oculta un mandato patriarcal. Por un lado, el cuerpo, el erotismo y las prácticas sexuales han encontrado nuevos espacios de libertad pero, por otro, están resurgiendo diversos fundamentalismos que niegan los derechos sexuales y reproductivos de las mujeres. Ante los discursos patriarcales de la transgresión y los fundamentalismos opresores, sostiene nuestra autora: "las mujeres hemos de buscar con inteligencia nuestro camino de placer, igualdad y autonomía" (23).

En el capítulo sexto, explica las razones por las que, en un contexto de anomia, como el actual, el ecofeminismo representa una alternativa ética ante la devastación medioambiental y la agudización de múltiples formas de desigualdad debidas a las políticas de desarrollo que han pauperizado las condiciones en que sobreviven las poblaciones del Sur. Asimismo, explora las posibilidades que plantea la "ciudadanía ecológica" y examina las alternativas que conducirían a una educación ambiental no androcéntrica que considere formas de conocimiento que han sido despreciadas, voces olvidadas en la historia de la ciencia y valores 
negados, como los desarrollados por el colectivo femenino y por culturas no occidentales. Siguiendo este hilo conductor, en el séptimo capítulo, nuestra filósofa subraya la importancia del diálogo intercultural en un marco que garantice el respeto a los derechos de las mujeres. Al respecto, considera que los movimientos de indígenas y campesinas pobres de Latinoamérica presentan una lección de interculturalidad de la que es necesario aprender.

En el octavo capítulo, reflexiona sobre los derechos de los animales en el contexto de la ética ecofeminista. Por una parte, recupera las historias de aquellas feministas que se encargaron de la defensa y el cuidado de los "otros" no humanos que también son capaces de amar y de sufrir. Por la otra, examina las relaciones de cuidado, afecto y protección que numerosas mujeres en el mundo tienen actualmente con los animales. Este fenómeno no sería el efecto de una "esencia femenina", puesto que hay varones que generosamente se han integrado a la lucha antiespecista, así como mujeres que son indiferentes e incluso contrarias a ella. A. Puleo observa que este intenso afecto comienza a configurarse como una visión crítica sobre el dominio androcéntrico y antropocéntrico. Se trataría, afirma, de una oscura resistencia al patriarcado en tanto "interrumpe el sistema de traspaso desigual de la energía del amor a través del hipercumplimiento de la virtud femenina por excelencia: el cuidado" (400).

En el último capítulo, la filósofa presenta la propuesta de un ecofeminismo crítico que reivindica los ideales ilustrados de libertad e igualdad; fomenta la universalización de la ética del cuidado; dialoga con las otras culturas en un marco de apertura y reconocimiento recíproco; se considera heredero de Darwin, al que reinterpreta en clave feminista; acepta con precaución los recursos de la ciencia y la tecnología; promueve la empatía y los sentimientos compasivos hacia los animales; se solidariza con las personas que están padeciendo las peores consecuencias del desarrollo ecocida, al mismo tiempo que se nutre de sus experiencias. Todo ello sin pretender ser una respuesta acabada, sino más bien una alternativa en la búsqueda de una sociedad más justa y sostenible.

En el laberinto del mundo actual, en el que se entrecruzan crisis de distinto signo, Alicia Puleo nos invita a guiarnos a través 
del hilo de la nueva Ariadna que ha nacido del encuentro entre feminismo y ecología. Su inteligencia no es un arma de la que alguien más se apropia para matar. Ella es la protagonista de ese otro mundo posible, y a su lado camina un nuevo Teseo. La madeja que ha ido tejiendo la lleva a descubrir su parentesco con el Minotauro, al que no concibe como un enemigo, sino como un semejante. En lugar de ayudar al héroe a dar muerte al "monstruo", esta Ariadna luchará por liberarlo e intentará convencer a su compañero de colaborar juntos en una cultura que haga posible la libertad, la igualdad, la sostenibilidad y la paz. 
